\title{
The days of future past
}

\author{
Neel K. Ranganath, MD, and Aubrey C. Galloway, MD
}

From the Department of Cardiothoracic Surgery, NYU Langone Health, New York, NY.

Disclosures: Authors have nothing to disclose with regard to commercial support.

Received for publication Aug 4, 2017; accepted for publication Aug 28, 2017; available ahead of print Sept 28, 2017.

Address for reprints: Aubrey C. Galloway, MD, Seymour Cohn Professor \& Chairman, Department of Cardiothoracic Surgery, NYU Langone Health, 530 1st Ave, Suite 9V, New York, NY 10016 (E-mail: Aubrey.Galloway@ nyumc.org).

J Thorac Cardiovasc Surg 2018;155:198-9

$0022-5223 / \$ 36.00$

Copyright (C) 2017 by The American Association for Thoracic Surgery

http://dx.doi.org/10.1016/j.jtcvs.2017.08.094

Nambiar and colleagues ${ }^{1}$ are to be commended for their large clinical series of minimally invasive off pump coronary artery bypass grafting $(\mathrm{CABG})$ procedures with bilateral internal thoracic arteries (ITAs), with excellent short-term outcomes, published in this issue of the Journal. This approach clearly required a great deal of innovation and technical expertise, and such innovation has played a critical role in the history of cardiac surgery. Nambiar and colleagues $^{1}$ are addressing a question that has been asked for more than 20 years: Is there a viable, minimally invasive CABG technique that is scalable and adds value? In the 1990s, Calafiore and associates ${ }^{2}$ and Subramanian and colleagues $^{3}$ described an off-pump left ITA to left anterior descending coronary artery grafting through a small left anterior thoracotomy. Similarly, our group and others ${ }^{4}$ investigated single and multivessel CABG through a minithoracotomy with cardiopulmonary bypass with an endoaortic balloon occluder. Although these approaches were innovative, like the approach described in this article, they were not widely adopted during the next 20 years. Why?

In the classic book The Innovator's Dilemma, Christensen ${ }^{5}$ asserts that when innovation is plotted against value, the curve is S-shaped. To add value, the innovation (or technique) must ultimately be scalable and reproducible (in this case by other surgeons and institutions). Then, assuming the technique is reproducible, long-term clinical outcome studies are necessary to assess the techniques against the standard of care.

$\mathrm{CABG}$ has remained the standard of care for coronary revascularization primarily because of the durability and long-term patency of the bypass grafts, which decrease the incidence of late cardiac events relative to other treatments. For example, the 5-year results of the SYNTAX (Synergy Between Percutaneous Coronary Intervention With Taxus and Cardiac Surgery) trial $^{6}$ demonstrated that the rates of myocardial infarction and repeat revascularization were significantly lower for patients undergoing CABG than for those undergoing percutaneous coronary interventions in a population with complex multivessel disease.

Another issue related to value is the use of single versus bilateral internal thoracic artery or radial artery grafts.

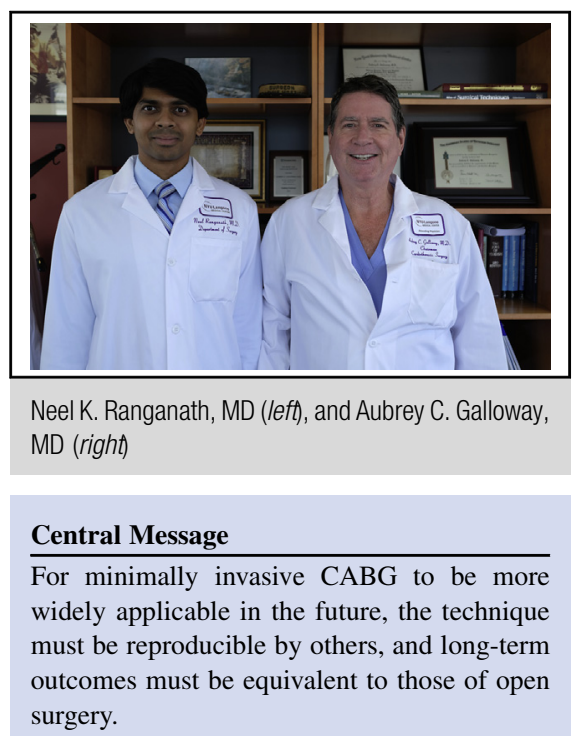

See Article page 190.

American College of Cardiology and American Heart Association evidence-based guidelines recommend single ITA grafting as a class I indication, with the use of a second ITA as class IIA and radial artery use as class IIb. Even this issue, however, is still being studied. Taggart and associates $^{7}$ recently demonstrated no significant difference in mortality or rates of cardiovascular events between single ITA and bilateral ITA grafts at 5 years, although sternal wound complications were more common in the bilateral ITA group. Further evaluation will likely help guide future recommendations, but at present the use of a second arterial graft is likely beneficial in suitable patients. Finally, although the off-pump versus on-pump issue is still debated, the positive results in most of the randomized trials have been in patients operated on through a sternotomy with the use of cardiopulmonary bypass, and this approach should still be considered the gold standard.

For the innovative approach of Nambiar and colleagues to be compared with the current standard of care, the technique would need to be scalable to other surgeons, and long-term outcomes would need to be equivalent. Certainly, Nambiar and colleagues ${ }^{1}$ are to be applauded for their innovation. But the question, "Is this the future?" remains very premature.

\section{References}

1. Nambiar P, Kumar S, Mittal CM, Saksena K. Minimally invasive coronary artery bypass grafting with bilateral internal thoracic arteries. Will this be the future? J Thorac Cardiovasc Surg. 2018;155:190-7. 
2. Calafiore AM, Di Giammarco G, Teodori G, Bosco G, D’Annunzio E, Barsotti A, et al. Left anterior descending coronary artery grafting via left anterior small thoracotomy without cardiopulmonary bypass. Ann Thoracic Surg. 1996;61: 1658-63; discussion 1664-5.

3. Subramanian VA, McCabe JC, Geller CM. Minimally invasive direct coronary artery bypass grafting: two-year clinical experience. Ann Thoracic Surg. 1997; 64:1648-53; discussion 1654-5.

4. Grossi EA, Groh MA, Lefrak EA, Ribakove GH, Albus RA, Galloway AC, et al. Results of a prospective multicenter study on port-access coronary bypass grafting. Ann Thorac Surg. 1999;68:1475-7.
5. Christensen CM. The Innovator's Dilemma: When New Technologies Cause Great Firms to Fail. Boston: Harvard Business School Press; 1997.

6. Mohr FW, Morice M, Kappetein AP, Feldman TE, Ståhle E, Colombo A, et al Coronary artery bypass graft surgery versus percutaneous coronary intervention in patients with three-vessel disease and left main coronary disease: 5-year follow-up of the randomised, clinical SYNTAX trial. Lancet. 2013;381: 629-38.

7. Taggart DP, Altman DG, Gray AM, Lees B, Gerry S, Benedetto U, et al; ART Investigators. Randomized trial of bilateral versus single internal-thoracicartery grafts. N Engl J Med. 2016;375:2540-9. 